\title{
Stereotipe Between Classed in Multicultural Processes in North Coastal of Java, Case of Kampung Pecinan and Kampung Gabahan Semarang
}

\author{
Eko Punto Hendro \\ \{eko.ipung@gmail.com\} \\ Faculty of Humanities, Diponegoro University \\ Jl. Prof. Soedarto, Tembalang, Semarang, 50275, Indonesia
}

\begin{abstract}
Indonesia is a country that uses the basic concept of the "bhineka tunggal ika" state, which is the concept of the country's population politics to unite the views of national unity among diverse populations or citizens, both racially, religiously and ethnically. Although it looks harmonious, especially in inter-ethnic relations, stereotypical views between ethnicities persist in varying intensities. The study was conducted with ethnographic methods in Kampung Pecinan (Chinatown) and Kampung Gabahan at Semarang. The stereotyped case finding, the population of Chinatown, which is mostly rich Chinese businessmen, shows fairly exclusive behavior regarding ethnic relations, while in neighboring Kampung Gabahan there are also many ethnic Chinese, they are more inclusive in their behavior. However, the issue of stereotypes remains strong in the two villages and is very influential on the models of social interaction. The emergence of stereotypical views is indeed inseparable from the existence of inter-class conflicts that were previously deliberately created by the Ducth Colonial Government in the past, and the effects drag on until now.
\end{abstract}

Keyword : stereotype, ethnic, Chinese, multycultural

\section{Introduction}

With the enactment of Law No. 12 of 2006 on August 1, 2006, concerning Citizenship, many people benefited, but there were also those who actually worried about it. Celebrities and people who are married to foreigners rejoice, because there is no need to conquer their child from a legitimate marriage and be born in Indonesia automatically to become Indonesian citizens. However, it seems that there are some parties who object or worry about the emergence of the law, because directly the legal structure will also greatly facilitate the ethnic Chinese to get Indonesian citizens, because previously they were very difficult to obtain. Officials in government agencies who have the right to issue letters about citizenship (the Civil Registry Office for example) are still asking for various conditions for Chinese people who want to get it.

Against ethnic Chinese in the corridors of conflict that are nuanced by SARA and the issue of assimilation at Orde Baru Government, they are under considerable pressure compared to other ethnic groups in Indonesia. Such is the strength of the politically charged pressure, which is linked to the issue of the Communists and the RRC Country, so this ethnic group eventually becomes quite exclusive, with the remaining economic power system (due to frozen socio-cultural potential) finally they are still able to exist in society and often raises 
potential social jealousy for conflict. The issue of intermingling here is put in the wrong position, so that it only produces Chinese with double standards. On the one hand, for example, by changing their name and appearance as if they were accommodating to the integration program, on the other hand their behavior was potentially a conflict with other ethnic groups. After the conflict actually happened they then complained that all this time it turned out that it had only been used as a dairy cow by the people who were impersonating the government.

\section{Research Methods}

The literature study was carried out to begin the research activity, which was then followed by data collection through observation and interview techniques for Chinese people in Semarang Chinatown. The collected data is then analyzed and explained descriptively.

\section{Result and Discussion}

In the Indonesian era now, when the government is striving to make this Republic become a country that upholds the rule of law, is socially just, democratic, cares about human rights and responds to differences as the Almighty God, it seems that policies towards ethnic Chinese have also been reviewed. Issuance of Presidential Decree No. 6 of 2000 was also a breath of fresh air for Chinese people who had suffered physically and psychologically during the New Orde era, because they were kept away from all elements that were upstream in their ancestral culture.

Quoting from the Kompas daily which cites the opinions of various experts and has been implemented in several countries, perhaps the multiculturalism approach is suitable to be applied to multi-ethnic communities such as Indonesia. This means that the central and regional governments must bridge the development of diverse cultural societies and prepare the media so that each developing culture can communicate well. Here the government must be able to develop wise cultural politics, provide conducive facilities and infrastructure, can be through moral appeal, encouragement or in the form of conducive legislation, so that people's cultures can develop well, be communicative and not conservatively closed [1].

As an example of what happened to the application of apheheid politics such as in South Africa, or discriminatory politics in Latin America that played down the role of even annihilating ethnic minorities, it did not occur in Indonesia, because this could be categorized as violating human rights. But precisely ethnic diversity can be used as the potential and traits of national culture, which in the end will shape the ethos of culture and work ethic towards a developed civil society. With the development of communicative cultures, it is expected to grow healthy competition between ethnic groups, which enables the growth of the process of acculturation and assimilation by itself.

The development of politics, economics, religions and foreign influences (modernization) as well as the complexity of the development of society towards Indonesian civil society that crosses ethnic boundaries, may have the potential to positively encourage relations between ethnic groups that are very conducive to a multicultural approach. Indeed, each of these processes can encourage each other to eliminate the social conflicts that arise from these processes. Problems in Indonesia, democracy that has not yet been completed, civil society is still very weak and modernization has not run smoothly, this is certainly weak points 
for multiculturalism programs which can actually be used for political commodities for irresponsible individuals.

So complicated and complicated the ethnic Chinese problems in Indonesia, so it is not surprising when in 1991 at Cornel University a symposium took place with the theme "The Role of the Indonesian Chinese in Shaping Modern Indonesian Life", came the statement: "The culture of identity and the position of the Chinese population within Indonesian society is a contentian one. The Chinese problem issue has been discussed within the Indonesian society itself and has proved a crucial question as Wether the Indonesian Chinese is their own culture of identity or should be integration or even assimilation into Indonesian culture.

In the current era of New Indonesia, where the government is clearly striving to make this Republic become a country that upholds the rule of law, is just, democratic, cares about human rights and responds to differences as the Almighty God, it seems that the Chinese ethnic policy was also reviewed. Issuance of Presidential Decree No. 6 of 2000 and Republic of Indonesia Law Number 6 of 2006 is a breath of fresh air for Chinese people who, during the New Order era physically and psychologically suffered, because they were kept away from all elements that were upstream in their ancestral culture. The existence of this policy is expected to make the Naga Nusantara rise from its long sleep.

Thus this reform era actually provided an opportunity for all parties, including ethnic Chinese, to prove themselves as legitimate heirs of the beloved republic. Actually, since the beginning of independence there were also Chinese ethnic leaders who were oriented to Indonesia, and were so determined to fight for the formation of nation and character building in Indonesia [2]. Long before the twentieth century, the Chinese who came on the archipelago had assimilated themselves with the natives, so that their characteristics disappeared altogether and they dissolved into one with the indigenous culture [3]. However, this good opportunity is not impossible to become an obstacle to the integration process, especially if their actions are missteped so that the impression is that the Indonesian Chinese are actually more exclusive. For this reason, the repositioning of ethnic Chinese in the New Indonesia Era needs to be carried out with great care, so that efforts to synergize the diversity of ethnic potential can go as expected.

In 1960 Willmott published the results of his research from 1954-1955 under the title "The Chinese of Semarang: A Changing Minority Community in Indonesia“ [4]. There are many things that can be utilized from the results of this study. The problem is that the profile of the Semarang Chinese community in the fifties is certainly different from the Chinese community in Semarang today. Besides that, the Chinese community of Semarang cannot be considered to represent all Chinese people in Indonesia. Given the fact that the Chinese community in Indonesia is so diverse, efforts are needed to obtain a picture of them.

In line with Willmott's statement that in the Southeast Asian region Chinese society was formed in line with or based on their main language, so Oetomo in his dissertation entitled "The Chinese of Pasuruan: Their Language and Identity" (1987) found three types of Indonesian Chinese society based on the use of language familiarity and the language of their daily solidarity. First, those who use regional languages, including Chinese people in Java, Madura, West Sumatra, Bali and Ujung Pandang, secondly, those who use local Malay language such as Chinese people who live in Jakarta, Menado, Kupang and Sorong, and third, those who speak Chinese, for example Hakka and Tio Ciu in West Kalimantan, Hokian in Riau Islands, Creole with Chinese elements prominent in Bangka and Belitung [5].

Given the magnitude of the function of language as a marker of identity characteristics or community pride and the influence of language on the culture, views and attitudes of the living community of speakers, then the mapping of Chinese ethnicity in 
Indonesia needs to be done in conjunction with efforts to obtain a more detailed picture of the profile of Indonesian Chinese.

Thus the current era actually provides more opportunities for all parties, including ethnic Chinese, to prove themselves as legitimate heirs of the beloved public. However, this good opportunity is not impossible to become an obstacle to the integration process, because their gait is often a misstep so that the impression is that the Indonesian Chinese are actually increasingly exclusive, and they often do not want to blend fully in society. In this case they are often reluctant to marry other ethinics in Indonesia, in terms of other ethnicities who have fully blended in the community which is shown in the absence of significant obstacles for those who want to hold inter-ethnic marriages.

Research conducted by Debora Wiriadinata (1998) entitled "Chinese Indonesian Dilemma: The Younger Generation of Chinese Indonesian, Search for Identity" conducted in four major cities, namely Surabaya, Bandar Lampung, Bandung and Jakarta, has found a dilemma faced by the younger generation of Chinese Indonesia. As Indonesian Indonesians they generally confessed to choosing, whether they would maintain their distinctive character of descent (descendants), or had to abandon all that was obtained from their ancestors and completely merge into the majority society. On the one hand they feel that as Indonesian citizens in the midst of this truly multi-ethnic nation, their culture and political rights have been denied. But on the other hand, they are proud of being Chinese, partly because of their high economic status, even though they do not feel protected from the aggressiveness of the majority group which can arise at any time [6].

From the above, it can be seen that they are actually strong, because a variety of pressures that minimize or marginalize them are responded to with full struggle so that they appear increasingly stronger and do not feel marginalized. The thing that needs to be eliminated is the stereotypical view of them and vice versa, which is certainly not conducive in the present and has the potential to trigger social conflict. But it seems they have not been able to eliminate the attitude of exclusivity that was built since the colonial era. The events of 1998 were dark evidence of this, because at that time Indonesia was hit by an economic crisis, so they were targeted, looted their goods until they were raped by their women. Previous periods also sporadically took place in Solo and Semarang to attack them. Their economic ability and exclusivity seems to be the trigger for conflict, which now seems to be increasingly real. They built luxury housing and apartment complexes in the middle of the city, such as in Jakarta, Semarang and Surabaya, of course causing the emergence of social jealousy that could explode again if the nation was hit by an economic crisis again. Until now, Sri Sultan Hamengkubuwono $\mathrm{X}$ as Governor, has continued to forbid the ownership of land (HM) for ethnic Chinese in the Special Region of Yogyakarta, because their attitude until now remains exclusive has not changed as in the past which does not want to join hands with the Jogjakarta people when they struggle through war with the Dutch to defend Indonesia's independence around 1948.

It is undeniable that the class division of the people in the Dutch East Indies was thought to be the trigger. During the colonial period the government divided the Dutch East Indies into three classes, the first class was occupied by Dutch and other European foreigners, the second class was occupied by foreign easterners, namely Chinese, Arabic and Japanese, while the third class was occupied by the common people (pribumi). Especially the Chinese were given the time to develop the economy and trade, and of course they should not move in the political field. Therefore at that time the indigenous and non-indigenous groups emerged. This was indeed a tactic of sheepfight carried out by the colonial government, which was caused by a previous period of major conflict between the VOC and the Chinese in Batavia 
which was called the event of "mistaken love" 1740-1741, and extended to Semarang. In Semarang, the Chinese people were actually assisted by the king of Mataram against the VOC.

This class politics was effectively carried out by the colonial government to oversee all community movements at that time, and this opportunity was also not wasted by ethnic Chinese citizens who occupied second class in society. Class politics that are inspired by the chaotic events that gave birth to exclusive behavior for ethnic Chinese until now. Before the events of the tussle, the Javanese had no problem with the Chinese, even in the 16th century it was estimated that the Chinese people actually helped the process of spreading Islam on Java.

In response to the above, in the multiculural approach, of course, the stereotypical view of ethnic Chinese must be changed, because it only produces a boomerang for society. In the current era of reform, with the framework of the multicultural approach, there should be a cultural dialogue between ethnic groups, with the hope of mutual respect among ethnic groups, and not to look at each other with suspicion. It is assumed that now ethnic Chinese are still in a position of confusion, because on the one hand while they are traveling out of the area, they usually refer to as Semarang people, Solo people, Pontianak people, Medan people and so on, because they were born and raised there. But in their original place they often have problems with their environment.

In Semarang Chinatown, the multicultural approach was carried out by holding the Semawis Market on certain days, during which the Chinese people mingled peddling and buying various foods, both Javanese and Chinese food. In addition, there are also many Javanese who are involved in Barongsai and Liong-liong arts held by several temples in Chinatown. Even so, the Chinese in Kampung Pecinan are still exclusive with regard to interethnic marital relations, while in the village next to it is Kampung Gabahan, some people have intermarried, although they still have to face environmental pressures, because they then have to mutually adapt to two Javanese and Chinese cultures.

\section{Conclusion}

The multiculturalism approach would be a strategic offer to change the model of other approaches that have ever existed. Because this approach is a fairly good new model but has not been widely tested, the government should implement wise cultural politics by providing infrastructure facilities in the form of moral appeal, encouragement or in the form of conducive legislation. Even if later there will be a process of acculturation or assimilation so that it will happen by itself and cannot be forced.

To reduce stereotypical views, the concept of multiculturalism was developed in Kampung Pecinan which was implemented in the form of organizing the Semawis Market and Barongsai arts. Nevertheless the exclusivity of Chinese people still persists especially in interethnic marital relations, which of course this is counterproductive and contrary to the politics of assimilation being carried out by the government.

\section{References}

[1] Kompas Daily March 14 (2001

[2] Greif, Stuart W.: WNI: Problematik Orang Indonesia Asal Cina, Jakarta : Grafiti, pp. 11(1991)

[3] Coppel, Charles A: Tionghoa Indonesia dalam Bisnis, Jakarta: Pustaka Sinar Harapan, pp. 37 (1994)

[4] Wilmott, Donald E.: The Chinese of Semarang: A Changing Minority in Indonesia, Ithaca Univ(1960)

[5] Oetomo :The Chinese of Pasuruan: Their Language and Identity" Dissertation (1987) 
[6] Wiriadinata, Debora, Chinese Indonesian Dilema: The Younger Generation of Chinese Indonesia, Search for Identity, Thesis Ohio University (1998) 